\title{
Rhyzopertha dominica (Coleoptera: Bostrichidae) infestation on seeds of Sorghum drummondii (Poaceae) in packages sold in retail stores
}

\author{
David Lopes Teixeira ${ }^{1 *}$ (D), Pedro Guilherme Lemes ${ }^{1}$, \\ Thiago Gomes dos Santos Braz² ${ }^{2}$ Germano Leão Demolin Leite ${ }^{1}$ (D), \\ José Cola Zanuncio ${ }^{3}$
}

\author{
${ }^{1}$ Universidade Federal de Minas Gerais, Instituto de Ciências Agrárias, Laboratório de Entomologia Aplicada à Área Florestal, Montes \\ Claros, MG, Brasil. \\ 2Universidade Federal de Minas Gerais, Instituto de Ciências Agrárias, Laboratório de Fenotipagem de Plantas, Montes Claros, MG, \\ Brasil. \\ ${ }^{3}$ Universidade Federal de Viçosa, Departamento de Entomologia/BIOAGRO, Viçosa, MG, Brasil.
}

\section{A R T I C L E I N F O}

Article history:

Received 28 December 2020

Accepted 27 April 2021

Available online 21 May 2021

Associate Editor: Regiane Cristina Bueno

\section{Keywords:}

Annual pasture

Lesser grain borer

Seed damage

Storage

Sudangrass

\begin{abstract}
A B S T R A C T
Insect damage to stored seeds is a challenge. Rhyzopertha dominica (Fabricius, 1792) (Coleoptera: Bostrichidae) is a major pest of seeds and grains in the world, but without record in seeds of the sudangrass (Sorghum drummondii (Poaceae)). The objective of this work was to report, for the first time, the occurrence and damage by $R$. dominica in $S$. drummondii seeds, sold in sealed packages in retail market. Four samples with 500 seeds each and without adult insects were separated from a package. The initial weight was obtained with a precision scale and the seeds were stored. The number of adult insects, the weight loss and the infestation rate of the seeds were evaluated 60 days later and the average between samples used to extrapolate the damage per package. An adult of $R$. dominica, on average, was obtained for each seven seeds and $54.06 \%$ of the seeds were damaged, with an average weight loss of $36.09 \%$. This is the first report of $R$. dominica in sudangrass seeds and the damage inflicted shows that this insect may cause losses in the quantity and quality of seeds due to its rapid populational growth.
\end{abstract}

The infestation of seeds by insects and their negative effects on food production, especially in family farming, is a challenge due to the reduction on seedling performance and the quality of the final product (Grenha et al., 2008; Santos et al., 2019). Damage caused by insect feeding on seeds may reduce nutrients, viability, weight and expose them to pathogens (Park et al., 2008; Papanikolaou et al., 2018; Srivastava et al., 2018; Wijayaratne et al., 2018).

Rhyzopertha dominica(Fabricius, 1792)(Coleoptera: Bostrichidae) is one of the major pest of stored seeds (Waongo et al., 2015; Perišić et al., 2018; Mishra et al., 2019), with a high host locating capacity and records of damage and outbreaks (Ahmad et al., 2013). The flow and transportation of infested products in the retail market may accelerate the spread of this pest in the world (Perez-Mendoza et al., 2004; Cordeiro et al., 2012; Rajan et al., 2018). This insect feeds on

\footnotetext{
* Corresponding author.

E-mail: davidlt.ufmg@hotmail.com (D.L. Teixeira)
}

the seeds of different plants but prefers those of cotton and wheat (Ahmad et al., 2013).

Sudangrass, Sorghum drummondii (Nees ex Steud.) Millsp. \& Chase (Poaceae) (Syn. Sorghum sudanense) used in crop rotation, soil cover and forage (Haile and Hofsvang, 2002), has no record of damage by $R$. dominica. This plant, in Brazil, is used as annual pastures and silage, with high nutritional value and dry matter productivity (Neumann et al., 2010).

The objective of this work was to record, for the first time, the occurrence and damage by $R$. dominica in $S$. drummondii seeds, sold in sealed packages at retail stores.

Sudangrass seeds were purchased from a local store, in a sealed cardboard box, with $2000 \mathrm{~g}$. These seeds were registered by the "Registro Nacional de Sementes" (RENASEM) (number 02776/2010) and were produced in Araçatuba, State of São Paulo, Brazil, in 2015. The package was open in June 2018 when the insects were found inside it.

The seeds, with insects, were brought to the Laboratory of Applied Forest Entomology (LAFE) in the campus of the Federal University of 
Table 1

Initial (ISW), final (FW) and reduction (WR) of seed weight, number of adults (NA) and seeds (NS) per sample, insects/seed ratio (ISR) per sample, number of damaged seeds (DS) by Rhyzopertha dominica (Coleoptera: Bostrichidae) and damaged seeds rate (DSR) per sample after 60 days

\begin{tabular}{|c|c|c|c|c|c|c|c|c|}
\hline & ISW (g) & $\mathrm{FW}(\mathrm{g})$ & WR (g) & NA & NS & ISR & DS & DSR \\
\hline Sample 1 & 5.06 & 3.22 & 1.84 & 86 & 500 & 6 & 190 & $38 \%$ \\
\hline Sample 2 & 6.13 & 3.49 & 2.64 & 86 & 500 & 6 & 358 & $71.60 \%$ \\
\hline Sample 3 & 5.76 & 3.78 & 1.98 & 65 & 500 & 8 & 259 & $51.80 \%$ \\
\hline Sample 4 & 5.78 & 4.00 & 1.78 & 65 & 500 & 8 & 274 & $54.80 \%$ \\
\hline Mean & 5.68 & 3.62 & 2.06 & 76 & 500 & 7 & 270 & $54.00 \%$ \\
\hline SE & 0.22 & 0.17 & 0.19 & 0.06 & - & 0.58 & 34.50 & \\
\hline Package & $2,000.00$ & $1,274.65$ & 725.35 & 26,761 & 176,056 & 7 & 95,174 & $54,05 \%$ \\
\hline
\end{tabular}

Seeds weight and infestation by Rhyzopertha dominica (Coleoptera: Bostrichidae) after 60 days.

Minas Gerais (UFMG) in Montes Claros, Minas Gerais State, Brazil. The average temperature and humidity of the room, where the seeds were stored, were $24.5 \pm 0.26 \mathrm{C}$ and $65 \pm 3.89 \%$, respectively. The insects were sent to Prof. Lêda Rita D’Antonino Faroni (Federal University of Viçosa, Minas Gerais, Brazil) for identification and confirmed to be $R$. dominica.

Four samples, with 500 seeds each, were separated from the package and sieved to remove residues and adult insects, leaving only the seeds and possible eggs and/or larvae. These seeds were weighted on a scale with $0.01 \mathrm{~g}$ of precision and each sample were stored in an individual $500 \mathrm{~mL}$ plastic container and evaluated after 60 days.

At 60 days, the seeds were sieved again to separate the adult insects, damaged and non-damaged seeds, the powder from larvae feeding and the fecal pellets. Adults, from each sample, were counted and preserved in $70 \%$ alcohol. The seed infestation rate, per sample, was based on damaged and intact seeds. The reduction in the seed weight, due to feeding by $R$. dominica was evaluated by the initial and final weight (60 days after) of the samples. An average was obtained, per parameter, and the results extrapolated to the whole pack content ( $2000 \mathrm{~g})$.

The average number of $R$. dominica adults emerged per sample was 76 with, approximately, 26,761 individuals for the total extrapolated to the pack (Table 1 ). The average weight of 500 seeds per sample was $5.68 \mathrm{~g}$. A $2000 \mathrm{~g}$ pack would have approximately 176,056 seeds resulting in, approximately, seven seeds per adult (Table 1 ). The high reproduction rate and short life cycle of this insect favors its population increase (Mubayiwa et al., 2018; Sawires and Elbassiouny, 2019). More than 13 adults per gram of sudangrass seeds shows that a physiological quality reduction may be occurring, as reported for wheat seeds with 12.5 adults per gram (Saad et al., 2018). The number of insects per seed and the weight loss indicates that the seeds damaged are, probably, no longer suitable for planting.

The percentage of damaged seeds per sample, after 60 days, was $54.06 \%$ ( 270 seeds), corresponding to approximately 95,174 damaged seeds in the whole box (Table 1). Active adults were still observed at the end of this 60-days period and the population growth of $R$. dominica was only halted when there were no intact seeds to be used as food for their larvae, although their adults could also feed on seed residues. The high percentage of damaged seeds can be explained by the high population density of $R$. dominica, as reported in wheat, rice and maize (Osuji, 1982; Saad et al., 2018; Ebadollahi and Borzoui, 2019). The high number of eggs per female ( 38 to 573 ) and short life cycle (25 to 65 days at temperatures of 25 to $34{ }^{\circ} \mathrm{C}$, respectively) explain the rapid multiplication of this insect (Edde, 2012). Rhyzopertha dominica larvae move quickly, selecting the most suitable seeds for feeding and can feed on a large number of them before they complete their development (Edde, 2012). A single larva may have fed from more than one seed, justifying the high rate of infestation, as reported for corn, chickpeas and lentils (Potter, 1935). The feeding of $R$. dominica, inside the seeds, may reduce the efficiency of chemical control in the management of this insect (Arthur et al., 2012; Perišić et al., 2018).

The average initial weight of the sample of 500 seeds of $R$. dominica was $5.68 \mathrm{~g}$ and the final $3.62 \mathrm{~g}$, a $36.09 \%$ reduction (Table 1 ). This represents a loss of $725.35 \mathrm{~g}$ in a $2000 \mathrm{~g}$ package in just 60 days. The weight loss of corn by this insect reached $7.2 \%$ and between $6.2 \%$ to $21.5 \%$ in Tanzania and Pakistan, respectively (Bakhtavar et al., 2019). The physiological quality of Cupania versalis Cambess seeds (Sapindaceae) was totally compromised when $38.2 \%$ of its content was consumed by this insect (Boscardin et al., 2012). Damage by $R$. dominica may be reducing the vigor and germination of sudangrass seeds, similar to the germination percentage, vigor and initial plant population of Sorghum bicolor L. Moench (Poaceae) that were reduced by $23.52 \%, 24,37 \%$ and $20.92 \%$, respectively, when at least $15 \%$ of the seed content was consumed (Netto et al., 1999).

The presence of $R$. dominica in closed packages of sudangrass seeds shows the need to invest in better packaging and processing of seeds to prevent infestation and damage by this insect (Lü and Ma, 2015; Daglish and Nayak, 2018; Bakhtavar et al., 2019; Waongo et al., 2019). The package, made with simple corrugated paper boxes, sealed, but without chemical protection, may have facilitated the damage to the seeds (Utono et al., 2014). Stored seed pests can identify the food source by the odor exhaled through porous materials such as cardboard, accessing the packaging or taking advantage of mechanical damage during handling (Lü and Ma, 2015).

This is the first record of $R$. dominica damaging sudangrass seeds. This insect may, possibly, reduce the seed quality due to the large number of adults, high infestation rate and weight loss of the seeds. The presence of this species in sealed commercial package shows that they are inadequate to prevent infestation by this insect, compromising their final use.

\section{Acknowledgments}

To "Conselho Nacional de Desenvolvimento Científico e Tecnológico (CNPq)", "Coordenação de Aperfeiçoamento de Pessoal de Nível Superior (CAPES)", "Fundação de Amparo à Pesquisa do Estado de Minas Gerais (FAPEMIG)" and "Programa Cooperativo sobre Proteção Florestal (PROTEF) do Instituto de Pesquisas e Estudos Florestais (IPEF) for financial support.

\section{Conflicts of interest}

The authors declare no conflicts of interest.

\section{References}

Ahmad, F., Ridley, A., Daglish, G. J., Burrill, P. R., Walter, G. H., 2013. Response of Tribolium castaneum and Rhyzopertha dominica to 
various resources, near and far from grain storage. J. Appl. Entomol. 137 (10), 773-781. http://dx.doi.org/10.1111/jen.12065.

Arthur, F. H., Ondier, G. O., Siebenmorgen, T. J., 2012. Impact of Rhyzopertha dominica (F.) on quality parameters of milled rice. J. Stored Prod. Res. 48, 137-142. http://dx.doi.org/10.1016/j.jspr.2011.10.010.

Bakhtavar, M. A., Afzal, I., Basra, S. M. A., Wahid, A., 2019. Implementing the 'dry chain' during storage reduces losses and maintains quality of maize grain. Food Secur. 11 (2), 345-357. http://dx.doi.org/10.1007/ s12571-019-00905-2.

Boscardin, J., Costa, E. C., Garlet, J., Oliveira, G. G., 2012. Primeiro registro de predação por microlepidóptero (Lepidoptera, Tortricidae, Olethreutinae) sobre sementes de Cupania versales Cambess. (Sapindaceae) no Sul do Brasil. Biotemas 25 (3), 305-309. http:// dx.doi.org/10.5007/2175-7925.2012v25n3p305.

Cordeiro, E. M. G., Campbell, J. F., Phillips, T. W., 2012. Movement and orientation decision modeling of Rhyzopertha dominica(Coleoptera: Bostrichidae) in the grain ass. Environ. Entomol. 45 (2), 410-419. http://dx.doi.org/10.1093/ee/nvv232.

Daglish, G. J., Nayak, M. K., 2018. Prevalence of resistance to deltamethrin in Rhyzopertha dominica (F.) in eastern Australia. J. Stored Prod. Res. 78, 45-49. http://dx.doi.org/10.1016/j.jspr.2018.06.003.

Ebadollahi, A., Borzoui, E., 2019. Growth performance and digestive enzymes activity of Rhyzopertha dominica (F.) (Coleoptera: Bostrichidade) feeding on six rice cultivars. J. Stored Prod. Res. 82, 48-53. http://dx.doi.org/10.1016/j.jspr.2019.04.004.

Edde, P. A., 2012. A review of the biology and control of Rhyzopertha dominica (F.) the lesser grain borer. J. Stored Prod. Res. 48, 1-18. http://dx.doi.org/10.1016/j.jspr.2011.08.007.

Grenha, V., Macedo, M. V., Monteiro, R. F., 2008. Predação de sementes de Allagoptera arenaria (Gomes) O'Kuntze (Arecaceae) por Pachymerus nucleorum Fabricius (Coleoptera, Chrysomelidae, Bruchinae). Rev. Bras. Entomol. 52 (1), 50-56. http://dx.doi.org/10.1590/S008556262008000100009.

Haile, A., Hofsvang, T., 2002. Host plant preference of the stem borer Busseola fusca (Fuller) (Lepidoptera: noctuidae). Crop Prot. 21 (3), 227-233. http://dx.doi.org/10.1016/S0261-2194(01)00089-8.

Lü, J., Ma, D., 2015. Effect of wheat flour packaging materials on infestation by Lasioderma serricome(F.). J. Food Prot. 78 (5), 1052-1055. http:// dx.doi.org/10.4315/0362-028X.JFP-14-438.

Mishra, G., Palle, A. A., Srivastava, S., Mishra, H. N., 2019. Disinfestation of stored wheat grain infested with Rhyzopertha dominica by ozone treatment: process optimization and impact on grain properties. J. Sci. Food Agric. 99 (11), 5008-5018. http://dx.doi.org/10.1002/jsfa.9742.

Mubayiwa, M., Mvumi, B. M., Stathers, T. E., Mlambo, S., Nyabako, T., 2018. Blanket application rates for synthetic grain protectants across agro-climatic zones: do they work? Evidence from field efficacy trials using sorghum grain. Crop Prot. 109, 51-61. http://dx.doi. org/10.1016/j.cropro.2018.01.016.

Netto, D. A. M., Borba, C. S., Oliveira, A. C., Azevedo, J. D., Andrade, R. V., 1999. Efeito de diferentes graus de dano mecânico na qualidade fisiológica de sementes de sorgo. Pesqui. Agropecu. Bras. 34 (8), 1475-1480. http://dx.doi.org/10.1590/S0100-204X1999000800020.

Neumann, M., Restle, J., Souza, A. N. M., Pellegrini, L. G., Zanette, P. M., Nornberg, J. L., Sandini, I. E., 2010. Desempenho vegetativo e qualitativo do sorgo forrageiro (Sorghum bicolor x Sorghum sudanense) em manejo de cortes. Rev. Bras. Milho Sorgo 9 (3), 298-313. http:// dx.doi.org/10.18512/1980-6477/rbms.v9n3p298-313.

Osuji, F. N. C., 1982. Development of the lesser grain borer, Rhyzopertha dominica, in maze kernels as affected by site of larval entry. Entomol. Exp. Appl. 31 (4), 381-394. http://dx.doi.org/10.1111/j.1570-7458.1982. tb03166.x.
Papanikolaou, N. E., Kavallieratos, N. G., Boukouvala, M. C., Malesios, C., 2018. Do temperature, relative humidity and interspecific competition alter the population size and the damage potential of stored-product insect pests? A hierarchical multilevel modeling approach. J. Therm. Biol. 78, 415-422. http://dx.doi.org/10.1016/j. jtherbio.2018.10.022.

Park, S., Arthur, R. H., Bean, S. R., Schober, T. J., 2008. Impact of differing population levels of Rhyzopertha dominica (F.) on milling and physicochemical properties of sorghum kernel and flour. J. Stored Prod. Res. 44 (4), 322-327. http://dx.doi.org/10.1016/j.jspr.2008.02.008.

Perez-Mendoza, J., Flinn, P. W., Campbell, J. F., Hagstrum, D. W., Throne, J. E., 2004. Detection of stored-grain insect infestation in wheat transported in railroad hopper-cars. J. Econ. Entomol. 97 (4), 14741483. http://dx.doi.org/10.1093/jee/97.4.1474.

Perišić, V., Vuković, S., Perišić, V. L., Pešić, S., Vukajlović, F., Andrić, G., Kljajić, P., 2018. Insecticidal activity of three diatomaceous earths on lesser grain borer, Rhyzopertha dominica F., and their effects on wheat, barley, rye, oats and triticale grain properties. J. Stored Prod. Res. 75, 38-46. http://dx.doi.org/10.1016/j.jspr.2017.11.006.

Potter, C., 1935. The biology and distribution of Rhyzopertha dominica (Fab.). Ecol. Entomol. 83, 449-482.

Rajan, T. S., Muralitharan, V., Daglish, G. J., Mohankumar, S., Rafter, M. A., Chandrasekaran, S., Mohan, S., Vimal, D., Srivastava, C., Loganathan, M., Walter, G. H., 2018. Flight of three major insect pests of stored grain in the monsoonal tropics of India, by latitude, season and habitat. J. Stored Prod. Res. 76, 43-50. http://dx.doi.org/10.1016/j. jspr.2017.12.005.

Saad, A. S. A., Tayeb, E. H. M., El-Shazli, M. M., Baheeg, S. A., 2018. Susceptibility of certain Egyptian and imported wheat cultivars to infestation by Sitophilus oryzae and Rhyzopertha dominica. Arch. Phytopathol. Pflanzenschutz 51 (1-2), 14-29. http://dx.doi.org/10. 1080/03235408.2018.1438779.

Santos, P. M., Simeone, M. L. F., Pimentel, M. A. G., Sena, M. M., 2019. Non-destructive screening method for detecting the presence of insects in sorghum grains using near infrared spectroscopy and discriminant analysis. Microchem. J. 149, 1-7. http://dx.doi. org/10.1016/j.microc.2019.104057.

Sawires, S. G., Elbassiouny, A. M., 2019. Effect of Gama irradiation on morphology of antennal sensilla of Rhyzopertha dominica (Coleoptera: bostrichidae). J. Radiat. Res. Appl. Sci. 12 (1), 234-239. http://dx.doi.org/10.1080/16878507.2019.1594093.

Srivastava, S., Mishra, G., Mishra, H. N., 2018. Ftnir-A Robust diagnostic tool for the rapid detection of Rhyzopertha dominica and Sitophilus oryzae infestation and quality changes in stored rice grains. Food Bioprocess Technol. 11 (4), 785-796. http://dx.doi.org/10.1007/ s11947-017-2048-3.

Utono, I. M., Coote, C., Gibson, G., 2014. Field study of the repellent activity of 'Lem-ocimum'-treated double bags against the insect pests of stored sorghum, Tribolium castaneum and Rhyzopertha dominica, in northern Nigeria. J. Stored Prod. Res. 59, 222-230. http://dx.doi.org/10.1016/j.jspr.2014.03.005.

Waongo, A., Ba, N. M., Dabiré-Binso, L. C., Sanon, A., 2015. Diversity and community structure of insect pests developing in stored sorghum in the Northern-Sudan ecological zone of Burkina Faso. J. Stored Prod. Res. 63, 6-14. http://dx.doi.org/10.1016/j.jspr.2015.05.002.

Waongo, A., Traore, F., Ba, M. N., Dabire-Binso, C., Murdock, L. L., Baributsa, D., Sanon, A., 2019. Effects of PICS bags on insect pests of sorghum during long-termstorage in Burkina Faso. J. Stored Prod. Res. 83, 261-266. http://dx.doi.org/10.1016/j.jspr.2019.07.010.

Wijayaratne, L. K. W., Arthur, F. H., Whyard, S., 2018. Methoprene and control of stored-product insects. J. Stored Prod. Res. 76, 161-169. http://dx.doi.org/10.1016/j.jspr.2016.09.001. 